\title{
Pengaruh Kompetensi Kepemimpinan dan Supervisi Kepala Sekolah Terhadap Kinerja Guru Smp di Kabupaten Nagekeo
}

\author{
Kristoforus Buku ${ }^{1 *}$, Achadi Budi Santosa ${ }^{2}$, Sukirman ${ }^{3}$, Enung Hasanah ${ }^{4}$ \\ ${ }^{1}$ (Pascasarjana Manajemen Pendidikan, Universitas Ahmad Dahlan, Indonesia). \\ * Corresponding Author. E-mail: kristoforusbuku01@gmail.com
}

\begin{tabular}{|l|l|l|}
\hline Receive: 05/03/2021 & Accepted: 05/03/2021 & Published: 28/03/2021
\end{tabular}

\begin{abstract}
Abstrak
Tujuan dilakukannya penelitian ini adalah untuk mengetahui pengaruh kompetensi kepemimpinan kepala sekolah dan pelaksanaan supervisi yang dilakukan oleh kepala sekolah terhadap kinerja guru SMP di Kabupaten Nagekeo, Provinsi Nusa Tenggara Timur. Angket dengan butir pernyataan tertutup digunakan sebagai instrumen pada penelitian ini dengan pendekatan deskriptif kuantitatif. Angket menggunakan skala Likert, dan telah diuji validitas dan reliabilitasnya. Regresi sederhana digunakan untuk melihat pengaruh masing-masing variabel bebas terhadap variabel terikat sedangkan regresi linear ganda dimaksudkan untuk melihat pengaruh variabel bebas terhadap variabel terikat secara simultan. Hasil penelitian menunjukkan terdapat pengaruh positif dan signifikan antara kompetensi kepemimpinan kepala sekolah terhadap kinerja guru sebesar 50,5\%. Supervisi kepala sekolah juga berpengaruh positif dan signifikan terhadap kinerja guru dengan persentase 43,6\%. Pengaruh positif dan signifikan secara bersama-sama ditunjukkan oleh kompetensi kepemimpinan kepala sekolah dan supervisi kepala sekolah terhadap kinerja guru dengan persentase mencapai $70,4 \%$.
\end{abstract}

Kata Kunci: Kompetensi kepemimpinan, supervisi kepala sekolah, kinerja guru, Nagekeo.

\begin{abstract}
The purpose of this study was to determine the effect of the principal's leadership competence and the implementation of supervision by the principal on the performance of junior high school teachers in Nagekeo Regency, East Nusa Tenggara Province. Questionnaire with closed statement items was used as an instrument in this study with a quantitative descriptive approach. The questionnaire uses a Likert scale, and its validity and reliability have been tested. Simple regression is used to see the effect of each independent variable on the dependent variable while multiple linear regression is intended to see the effect of the independent variable on the dependent variable simultaneously. The results showed a positive and significant influence between the principal's leadership competence on teacher performance by 50.5\%. Principal supervision also has a positive and significant effect on teacher performance, with a percentage of 43.6\%. The positive and significant effect is simultaneously shown by the leadership competence of the principal and the supervision of the principal on teacher performance with a percentage of reaching $70.4 \%$.
\end{abstract}

Keywords: Leadership competence, principal supervision, teacher performance, Nagekeo. 


\section{Pendahuluan}

Tugas manajemen kependidikan di sekolah dipandu oleh kepala sekolah. Menjadi kepala sekolah memerlukan kemampuan manajerial yang baik dan mumpuni sehingga dapat memaksimalkan segala potensi untuk mencapai visi-misi sekolah. Aspek manajerial yang dimaksud antara lain menyusun Rencana Kerja Tahunan (RKT), Rencana Kerja Jangka Menengah (RKJM), memiliki struktur organisasi, membuat surat penugasan guru, dan mengevaluasi hasil monev kepala sekolah. Umumnya setiap sekolah sudah memiliki RKT dan RKJM, walau pada kenyataan yang ditemui di lapangan, penyusunannya tidak berdasarkan evaluasi diri sekolah, tidak melibatkan seluruh komponen sekolah, sehingga kurang mendapat respon positif.

\begin{tabular}{lll}
\multicolumn{1}{c}{ Kepala } & sekolah yang profesional \\
dituntut & memiliki & kompetensi \\
kepemimpinan & yang mumpuni dalam \\
mengelola & institusi & pendidikan.
\end{tabular}

Kepemimpinan sebagai fungsi manajemen menjadi faktor penting guna mencapai tujuan sebuah institusi atau organisasi. Pemimpin pada satuan pendidikan harus dapat menciptakan hubungan yang harmonis terhadap seluruh komponen pendidikan guna pembinaan dan pengembangan kerjasama antar personal.

Peraturan Menteri Pendidikan Nasional Nomor 13 tahun 2007 mensyaratkan untuk menduduki jabatan kepala sekolah seseorang wajib memiliki sertifikat kepala dari lembaga pemerintahan. Kualifikasi akademik minimal untuk jabatan kepala sekolah adalah sarjana atau diploma empat, berusia maksimal 56 tahun saat dilantik, dan pengalaman mengajar minimal lima tahun dengan pangkat minimal III/C (Lestari, 2018). Seorang kepala sekolah juga dituntut memiliki kompetensi-kompetensi berikut, antara lain kompetensi supervisi, manajerial, kepribadian, kewirausahaan, dan sosial. Namun pada praktiknya, perekrutan yang dilakukan kurang memperhatikan kompetensi kepemimpinan para calon kepala sekolah.

Dimensi kompetensi supervisi seorang kepala sekolah meliputi aspek perencanaan, pelaksanaan, dan tindaklanjut kegiatan guna peningkatan profesionalisme guru (Selvia, 2015). Kepala sekolah wajib melaksanakan supervisi sebagai bentuk pengawasan dan perbaikan terhadap seluruh rangkaian proses pendidikan yang terjadi di lingkungan sekolah (Adi, 2016).

Menurut Sahertian (dalam Herly, 2014), supervisi merupakan upaya pemberian layanan bagi guru dalam rangka perbaikan dan peningkatan kualitas pembelajaran. Secara sederhana supervisi merupakan alat kendali mutu pendidikan. Melalui supervisi, kepala sekolah dapat membina dan memacu para guru menjadi lebih profesional sehingga kegiatan belajar menjadi semakin efektif sehingga tujuan pendidikan dapat tercapai.

Profesionalisme guru merupakan kemampuan guru menjalankan tugas dan perannya sebagai pendidik, meliputi aspek perencanaan, pelaksanaan, dan evaluasi kegiatan belajar (Nurjanah, 2011). Dengan demikian kepala sekolah berkewajiban merencanakan, melaksanakan, dan mengevaluasi supervisi akademik secara periodik dan berkelanjutan.

Sudiyono dan Prasojo (dalam Indrawati, 2017) menyatakan hasil supervisi akademik dapat ditindaklanjuti dengan memberi penghargaan bagi guru yang telah mencapai standar, teguran dan pembinaan terhadap guru yang belum memenuhi standar, serta memfasilitasi maupun memberi kesempatan mengikuti pelatihan lebih lanjut guna peningkatan profesionalisme guru. Kepala sekolah juga perlu membantu guru menentukan metode pembelajaran yang sesuai (Evriani, 2017).

Guru sebagai tenaga pendidik perlu memiliki kompetensi kependidikan yang menunjang pembelajaran yang efektif. Realita yang ada, guru masih dibebani dengan tugas tambahan lain yang dapat menyebabkan pembelajaran yang dijalankan tidak efektif yang belum mampu 
menjawab tuntutan mutu pendidikan. Hal lain yang juga mempengaruhinya adalah distribusi guru yang tidak merata, belum terjaminnya kesejahteraan guru serta manajemen pada satuan pendidikan yang kurang professional. Supervisi akademik kepala sekolah terhadap guru sangat bisa dimaksimalkan untuk mengatasi masalah pembelajaran (Mukhtar, 2015).

Pada kenyataannya masih ditemui banyak ketimpangan karena kemampuan manajerial kepala sekolah yang kurang baik serta jarang melakukan supervisi seperti yang terjadi pada lingkup pemerintahan kabupaten Nagekeo, Provinsi Nusa Tenggara Timur (NTT). Nagekeo sebagai salah satu kabupaten termuda di NTT memiliki jumlah sekolah tingkat menengah pertama sebanyak 61 sekolah (dapodik.kemdikbud.go.id).

Kepala sekolah yang jarang melaksanakan supervisi menyebabkan kinerja guru relatif sulit diukur dan proses pembelajaran tidak maksimal. Pelaksanaan supervisi kepala sekolah hanya dilakukan jika sekolah tersebut akan dimonitoring oleh pengawas sekolah yang mana masih sebatas pemenuhan kewajiban administrasi tanpa memperhatikan kualitas perencanaan dan pelaksanaan serta rencana tindak lanjutnya. Selain itu di Nagekeo hingga saat ini belum ada data empirik hasil penelitian yang menunjukan korelasi antara supervisi kepala sekolah terhadap kinerja yang dimiliki oleh guru menengah pertama.

Penelitian terdahulu telah berhasil mengkaji pengaruh beberapa variabel terhadap kinerja guru. Secara simultan variabel motivasi kerja, supervisi, serta disiplin kerja mempengaruhi kinerja guru dengan persentase $65,4 \%$. Secara parsial kinerja guru $17,56 \%$ dipengaruhi oleh disiplin kerja, 27,77\% oleh motivasi kerja, dan $15,21 \%$ oleh supervisi akademik (Wahyudi, Thomas, \& Setiyani, 2012). Penelitian Amanda, Salam, \& Saggaf (2017) mendapati supervisi kepala sekolah tidak signifikan mempengaruhi kinerja guru dengan persentase hanya $10,5 \%$ sedangkan $89,5 \%$ kinerja guru dipengaruhi variabel lain. Menurut Isjoni (2017) terdapat hubungan yang berbanding lurus antara supervisi kepala sekolah dengan profesionalisme guru SMA di Pekanbaru.

Penelitian ini melakukan peninjauan terhadap kedua variabel sekaligus yaitu pengaruh kepemimpinan dan supervisi kepala sekolah terhadap kinerja guru, baik pengaruh secara terpisah maupun simultan. Hasil penelitian ini diharapkan menjadi menjadi bahan pertimbangan kepala sekolah dalam meningkatkan kompetensi kepemimpinan serta pelaksanaan supervisi yang terencana demi perbaikan kinerja guru serta kualitas manajemen pendidikan di Nagekeo maupun daerah lain di Indonesia.

\section{Metode}

Jenis, Waktu dan Tempat Penelitian

Penelitian ini memakai pendekatan deskriptif kuantitatif dengan analisis numerical. Data penelitian yang dikumpulkan akan diubah menjadi angka untuk selanjutnya dilakukan analisis statistik guna melihat pengaruh kompetensi kepemimpinan serta supervisi kepala sekolah terhadap kinerja para guru SMP di Kabupaten Nagekeo. Analisis data memakai pendekatan deskriptif serta inferensial. Penelitian dilaksanakan antara bulan Agustus sampai Oktober 2020, bertempat di Sekolah Menengah Pertama lingkup Kabupaten Nagekeo, NTT.

\section{Populasi dan Sampel Penelitian}

Populasi dalam penelitian ini adalah semua guru dari tujuh SMPN di Kabupaten Nagekeo yang berjumlah 162 orang (Tabel 1). Pada penelitian ini penentuan sampel memakai teknik proporsional random sampling dengan proporsi yang merata sesuai jumlah populasi tiap sekolah. Jumlah sampel ditentukan menggunakan persamaan Slovin (Umar dalam Indriyani, 2018):

$n=\frac{N}{1+N e^{2}}$

Dengan $n$ adalah sampel, $N$ adalah populasi, dan $e$ merupakan persentase error pengambilan sampel $(5 \%)$. 
Berdasarkan persamaan (1) jumlah sampel dalam penelitian ini sebanyak 115 orang. Selanjutnya dilakukan perhitungan proporsi sampel tiap sekolah objek penelitian. Populasi penelitian dan proporsi sampel tiap sekolah ditampilkan di Tabel 1.

Tabel 1. Populasi dan Proporsi Sampel

\begin{tabular}{clcc}
\hline No & \multicolumn{1}{c}{ Nama Sekolah } & Populasi & Sampel \\
\hline 1 & SMPN 1 Aesesa & 29 & 20 \\
2 & SMPN 3 Aesesa & 34 & 24 \\
3 & SMPN 3 Boawae & 18 & 13 \\
4 & SMPN 4 Boawae & 15 & 11 \\
5 & SMPN 5 Boawae & 13 & 9 \\
6 & SMPN 6 Boawae & 13 & 9 \\
6 & SMPN 1 Nangaroro & 22 & 16 \\
7 & SMPN 1 Mauponggo & 18 & 13 \\
\hline & $\quad$ Jumlah & 162 & 115 \\
\hline
\end{tabular}

Teknik Pengumpulan Data dan Variabel Penelitian

Penelitian memakai jenis angket tertutup yang memungkinkan responden mencentang $(\sqrt{ })$ pada pilihan jawaban yang sesuai. Untuk mengatasi permasalahan teknis dalam pengisian maka angket perlu dilengkapi dengan pedoman pengisian. Selanjutnya angket akan diuji untuk melihat validitas dan reliabelitas instrumen sebelum diberikan kepada responden.

Variabel bebas dalam penelitian ini yakni kompetensi kepemimpinan $\left(\mathrm{X}_{1}\right)$ serta supervisi kepala sekolah $\left(\mathrm{X}_{2}\right)$, sementara variabel terikat yakni kinerja guru.

Instrumen Penelitian

Penyusunan instrumen pengumpulan data dilakukan mengikuti langkah berikut:

1. Identifikasi variabel sesuai masalah penelitian;

2. Penjabaran variabel;

3. Penentuan indikator tiap sub variabel;

4. Penyusunan deskriptor tiap indikator;

5. Perumusan deskriptor menjadi butir instrumen;

Jawaban responden pada kuisioner dapat dikonversi menjadi angka memakai skala Likert dengan nilai satu sampai dengan empat. Kisi-kisi instrumen tiap variabel ditampilkan pada Tabel 2, 3, dan 4 .

Tabel 2. Kisi Instrumen Kompetensi Kepemimpinan Kepala Sekolah

\begin{tabular}{|c|c|c|c|}
\hline No & Dimensi & Indikator & Nomor butir \\
\hline 1 & Edukator & Meningkatkan profesionalisme serta membina & $1,2,3,4,5$ \\
\hline 2 & Manajer & $\begin{array}{l}\text { kepribadian (moral, mental, fisik, artistik) guru. } \\
\text { Merencanakan dan memberdayakan guru pada } \\
\text { program sekolah serta mengevaluasinya. }\end{array}$ & $6,7,8,9$ \\
\hline 3 & Administrator & $\begin{array}{l}\text { Kemampuan mengelola administrasi pembelajaran, } \\
\text { keuangan dan sarana-prasarana. }\end{array}$ & $\begin{array}{l}10, \quad 11, \quad 12, \\
13,14\end{array}$ \\
\hline 4 & Supervisor & $\begin{array}{l}\text { Kemampuan menyusun, melaksanakan dan } \\
\text { mengevaluasi program supervisi. }\end{array}$ & $15,16,17$ \\
\hline 5 & Leader & $\begin{array}{l}\text { Kemampuan membuat keputusan, kemampuan } \\
\text { komunikasi, serta mendelegasikan tugas. }\end{array}$ & $18,19,20,21$ \\
\hline 6 & Inovator & $\begin{array}{l}\text { Kemampuan mengemukakan ide baru } \\
\text { pengembangan sekolah serta pelaksanaannya. }\end{array}$ & 22,23 \\
\hline
\end{tabular}

Tabel 3. Kisi Instrumen Supervisi Kepala Sekolah

\begin{tabular}{llll}
\hline No & \multicolumn{1}{c}{ Dimensi } & \multicolumn{1}{c}{ Indikator } & \multicolumn{1}{c}{ Butir pernyataan } \\
\hline 1 & Perencanaan & Rencana program supervisi. & $1,2,3,4,5$ \\
& & $\begin{array}{l}\text { Buku catatan, instrumen supervisi, serta jadwal } \\
\text { pelaksanaan supervisi }\end{array}$ & $6,7,8,9,10$ \\
2 & \multirow{2}{*}{ Pelaksanaan } & Menentukan sasaran supervisi. & 11,12 \\
& & Menentukan teknik supervisi & 13,14 \\
3 & Tindak lanjut & Reward and punishment & 15,16 \\
\hline
\end{tabular}


Tabel 4. Kisi Instrumen Kinerja Guru

\begin{tabular}{llll}
\hline \multirow{2}{*}{ No } & \multicolumn{1}{c}{ Dimensi } & \multicolumn{1}{c}{ Indikator } & \multicolumn{1}{c}{ Butir pernyataan } \\
\hline 1 & Perencanaan & Menyusun perangkat pembelajaran. & $1,2,3,4,7,8,9,10$, \\
2 & Pembelajaran & Metode dan media pembelajaran. & $5,6,7,8,11,12$ \\
& & & $13,14,15,16,17$, \\
3 & Evaluasi & Penggunaan instrumen penilaian. & 18 \\
& & & 19,20 \\
4 & Kepribadian & Disiplin dan tegas & 21 \\
\hline
\end{tabular}

Uji coba instrumen diberikan kepada 15 responden di luar sampel penelitian. Uji validitas menggunakan product-moment Pearson (r tabel untuk sampel 15 orang adalah 0,514), sedangkan uji reliabilitas menggunakan Alpha Cronbach.

Hasil uji validitas instrumen kompetensi kepemimpinan kepala sekolah menunjukkan nilai koefisien korelasi > 0,514. Sehingga dapat dikatakan semua butir pernyataannya valid. Koefisien Alpha Cronbach pada uji reliabilitas adalah sebesar 0,7501, sehingga dapat dikatakan instrumen ini bersifat reliabel.

Uji validitas instrumen supervisi kepala sekolah memperoleh hasil hitung koefisien korelasi > 0,514 untuk semua butir yang berarti keseluruhan butir pernyataan valid. Koefisien Alpha Cronbach yang diperoleh pada uji reliabilitasnya yaitu sebesar 0,9024 dengan demikian, instrumen supervisi kepala sekolah bersifat reliabel.

Pada instrumen kinerja guru, perhitungan koefisien korelasi Productmoment Pearson > 0,514 untuk semua butir yang berarti instrumen ini bersifat valid. Uji reliabilitas memperoleh nilai koefisien Alpha Cronbach sebesar 0,9622 sehingga dapat diartikan instrumen bersifat reliabel.

\section{Teknik Analisa Data}

Pendeskripsian data hasil penelitian tanpa generalisasi data dilakukan dengan analisis deskriptif untuk mendapatkan data rerata nilai, median, modus, skor maksimum, skor minimum, kesalahan standar rata-rata, rentang, simpang baku, varian, serta distribusi frekuensi.
Analisis inferensial dipakai untuk menganalisis data sampel penelitian yang selanjutnya penarikan kesimpulan diberlakukan kepada seluruh populasi. Uji prasyarat analisis berupa uji normalitas, uji heteroskedastisitas, uji linearitas, serta uji multikolinearitas data. Pengujian hipotesis penelitian berdasarkan uji regresi sederhana untuk korelasi variabel bebas secara terpisah terhadap variabel terikat dan uji regresi berganda untuk melihat korelasi variabel bebas secara simultan terhadap variabel terikat. Tabulasi dan analisis data dilakukan memanfaatkan aplikasi Microsoft Excel dan IBM SPSS for Windows.

Hipotesis pada penelitian ini dapat dijabarkan sebagai berikut:

$\mathrm{H}_{1}=$ Kompetensi kepemimpinan kepala sekolah berpengaruh positif dan signifikan terhadap kinerja guru.

$\mathrm{H}_{2}=$ Supervisi kepala berpengaruh positif dan signifikan terhadap kinerja guru.

$\mathrm{H}_{3}=$ Kompetensi kepemimpinan kepala sekolah dan supervisi kepala sekolah berpengaruh positif dan signifikan terhadap kinerja guru.

\section{Hasil dan Pembahasan}

Deskripsi Data Penelitian

Analisis data yang dilakukan terhadap hasil pengisian angket kompetensi kepemimpinan kepala sekolah $\left(\mathrm{X}_{1}\right)$ menunjukkan perolehan skor terendah 76 dan skor tertinggi 91. Rata-rata nilai 82,13 dengan median 82, standar deviasi 3,53 serta varians 12,39 . Penentuan jumlah kelas yang diperbolehkan menggunakan aturan Sturges (Sutrisno, Ashadi, Tanjung, \& 
Tyas, 2020) adalah 7,8 dibulatkan menjadi 8 dengan rentang interval 2. Sebaran frekuensi kompetensi kepemimpinan kepala sekolah ditampilkan pada Gambar 1.

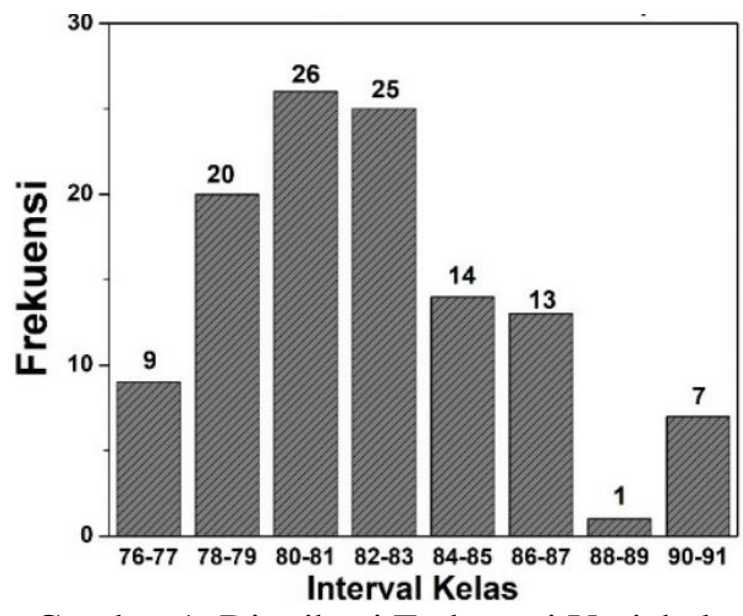

Gambar 1. Distribusi Frekuensi Variabel

Kepemimpinan Kepala Sekolah

Hasil pengisian instrumen supervisi kepala sekolah $\left(\mathrm{X}_{2}\right)$ memperoleh skor minimum 50 dan skor maksimum 63. Ratarata nilai sebesar 58,02 dengan median 58, standar deviasi 3,80 serta varians 14,35. Banyak kelas yang diperbolehkan adalah 7,8 dibulatkan menjadi 8 dengan rentang interval 2. Frekuensi variabel supervisi kepala sekolah ditunjukan Gambar 2.

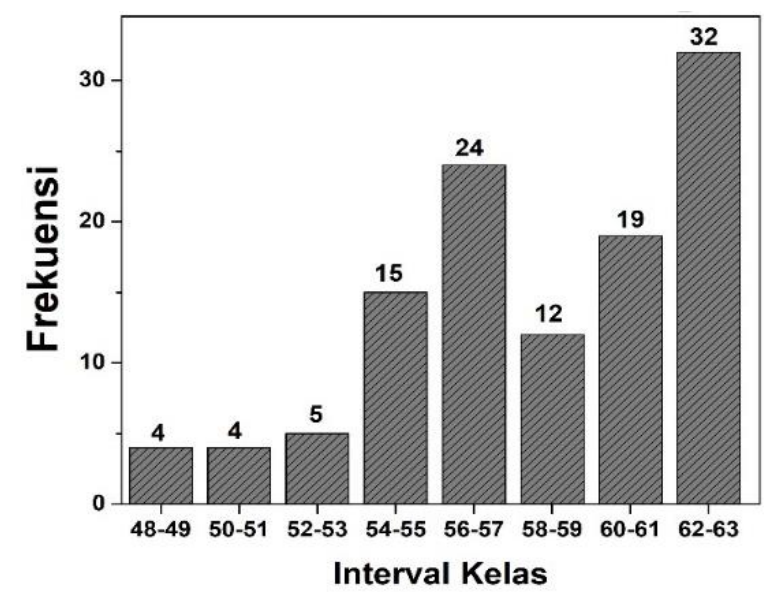

Gambar 2. Distribusi Frekuensi Variabel

Supervisi Kepala Sekolah

Hasil pengisian instrumen kinerja guru (Y) memperoleh skor minimum 64 dan skor maksimum 79. Rata-rata sebesar 70,86 dengan median 71 , standar deviasi 3,98 serta varians 15,77 . Kelas yang diperbolehkan sebanyak 7,8 dibulatkan menjadi 8 dengan rentang interval 2 . Sebaran frekuensi kinerja guru ditampilkan pada Gambar 3.

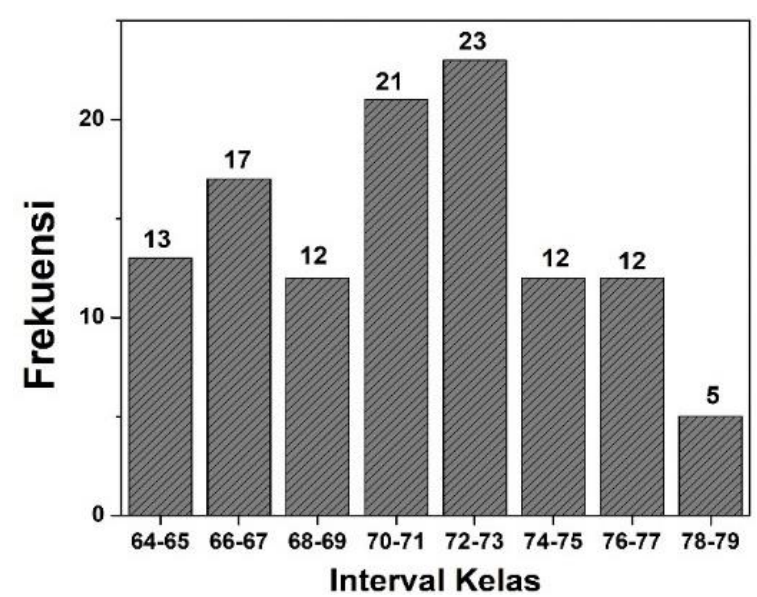

Gambar 3. Distribusi Frekuensi Variabel Supervisi Kepala Sekolah

Uji Prasyarat Analisis

1) Uji normalitas data

Normalitas distribusi sekelompok data dapat diselidiki memakai uji Kolmogorov-Smirnov (Lilliefors, 1967). Pengujian normalitas dilakukan dengan terlebih dahulu membuat hipotesis.

$\mathrm{H}_{0}=$ Kepemimpinan dan supervisi kepala sekolah terhadap kinerja guru memiliki galat taksiran berdistribusi normal.

$\mathrm{H}_{\mathrm{a}}=$ Kepemimpinan dan supervisi kepala sekolah terhadap kinerja guru memiliki galat taksiran tidak berdistribusi normal.

Data dikatakan berdistribusi normal jika nilai signifikansi lebih dari 0,05 sehingga $\mathrm{H}_{0}$ diterima. Pengujian untuk normalitas data menggunakan SPSS for Windows dan ditampilkan pada Tabel 5. Hasil pengujian menunjukkan signifikansi lebih dari 0,05 sehingga $\mathrm{H}_{0}$ diterima. Dengan demikian kompetensi kepemimpinan dan supervisi kepala sekolah terhadap kinerja guru memiliki galat taksiran yang berdistribusi normal. 
Tabel 5. Uji Normalitas

\begin{tabular}{llrrr}
\hline & & $\begin{array}{c}\text { Kompetensi } \\
\text { Kepemimpinan }\end{array}$ & $\begin{array}{c}\text { Supervisi Kepala } \\
\text { Sekolah }\end{array}$ & $\begin{array}{c}\text { Kinerja } \\
\text { Guru }\end{array}$ \\
\hline $\mathrm{N}$ & & 115 & 115 & 115 \\
Normal Parameters & & & \multicolumn{1}{c}{$b$} \\
& Mean & 3,0847 & 2,9630 & 3,0849 \\
& Std. Deviation & 0,53156 & 0,42719 & 0,47901 \\
Most Extreme Difference & Absolute & 0,124 & 0,123 & 0,117 \\
& Positive & 0,079 & 0,091 & 0,060 \\
& Negative & $-0,124$ & $-0,123$ & $-0,117$ \\
Kolmogorov-Sminrnov Z & & 1,326 & 1,316 & 1,260 \\
Asymp. Sig (2-tailed) & & 0,059 & 0,063 & 0,084 \\
\hline
\end{tabular}

2) Uji Heteroskedastisitas

Uji heterokedastisitas dipakai untuk mengamati ketidaksamaan variance residual pada model regresi (Mardiyati, Ahmad, \& Ria, 2012). Dalam penelitian ini uji Glejser menggunakan aplikasi SPSS for Windows dipakai untuk menyelidiki heteroskedastisitas. Jika nilai signifikansi variabel bebas terhadap residu absolut di atas 0,05 maka tidak terjadi heteroskedastisitas.

Berdasarkan Tabel 6, nilai signifikansi kompetensi kepemimpinan terhadap residu absolutnya adalah 0,156 (Sig. >0,05), sedangkan supervisi kepala sekolah memiliki signifikansi 0,098 (Sig. $>0,05)$. Dengan demikian tidak terjadi heteroskedastisitas pada varians kelompok.

Tabel 6. Uji Hetersoskedastisitas

\begin{tabular}{|c|c|c|c|c|c|c|}
\hline \multirow[b]{2}{*}{ Model } & & \multicolumn{2}{|c|}{$\begin{array}{c}\text { Unstandardized } \\
\text { Coefficient }\end{array}$} & \multirow{2}{*}{$\begin{array}{c}\begin{array}{c}\text { Standardized } \\
\text { Coefficient }\end{array} \\
\text { Beta } \\
\end{array}$} & \multirow[t]{2}{*}{$t$} & \multirow[t]{2}{*}{ Sig. } \\
\hline & & $B$ & Std. Error & & & \\
\hline \multirow[t]{3}{*}{1} & (Constant) & 0,096 & 0,134 & & 0,716 & 0,476 \\
\hline & Kompetensi Kepemimpinan & $-0,061$ & 0,042 & $-0,164$ & $-1,427$ & 0,156 \\
\hline & Supervisi Kepala Sekolah & 0,088 & 0,053 & 0,192 & 1,670 & 0,098 \\
\hline
\end{tabular}

3) Uji Linearitas

Uji linearitas dipakai untuk melihat hubungan variabel bebas dan variabel terikat pada model regresi. Variabel dikatakan linear jika nilai signifikansi Deviation from Linearity > 0,05. Uji linearitas kompetensi kepemimpinan terhadap kinerja guru dan supervisi kepala sekolah terhadap kinerja guru ditunjukan pada Tabel 7 dan 8 .
Tabel 7 menunjukkan signifikansi Deviation from Linearity 0,072 (Sig. > 0,05), dengan demikian hubungan kompetensi kepemimpinan kepala sekolah dan kinerja guru bersifat linear. Sedangkan berdasarkan Tabel 8 diperoleh nilai signifikansi 0,126 (Sig. > 0,05). Dengan demikian hubungan supervisi kepala sekolah dan kinerja guru bersifat linear.

Tabel 7. Uji Linearitas Kompetensi Kepemimpinan Kepala Sekolah terhadap Kinerja Guru

\begin{tabular}{|c|c|c|c|c|c|}
\hline & & & Mean Square & $\mathrm{F}$ & Sig. \\
\hline Kinerja Guru* & Between & (Combined) & 0,463 & 5,619 & 0,000 \\
\hline Kompetensi & Groups & & & & \\
\hline Kepemimpinan & & Linearity & 15,144 & 183,675 & 0,000 \\
\hline Kepala Sekolah & & Deviation from Linearity & 0,122 & 1,479 & 0,072 \\
\hline
\end{tabular}


Jurnal Edumaspul, 5 (1), Year 2021- 536

(Kristoforus Buku, Achadi Budi Santosa, Sukirman, Enung Hasanah)

Tabel 8. Uji Linearitas Supervisi Kepala Sekolah terhadap Kinerja Guru

\begin{tabular}{lllccc}
\hline & & & Mean Square & F & Sig. \\
\hline Kinerja Guru* & Between & (Combined $)$ & 0,745 & 7,514 & 0,000 \\
Supervisi Kepala & Groups & & & & \\
Sekolah & & Linearity & 14,034 & 141,542 & 0,000 \\
& & Deviation from Linearity & 0,141 & 1,422 & 0,126 \\
\hline
\end{tabular}

4) Uji Multikolinearitas

Uji multikolinearitas bertujuan mengamati tingkat korelasi antar variabel bebas pada model regresi (Helmiawan, Akbar, \& Sofian, 2019). Adanya multikolinearitas menyebabkan koefisien regresi variabel bebas sulit ditentukan dan standar deviasi mencapai tak hingga. Uji multikolinearitas menggunakan SPSS dengan dasar pengambilan keputusannya jika Tolerance lebih besar dari 0,10 dan Variance Inflation Factor (VIF) kurang dari 10,00 maka tidak terdapat multikolinearitas antar variabel. Berdasarkan Tabel 9 diperoleh Tolerance 0,657 dan VIF 1,523, sehingga multikolinearitas antar-variabel bebas tidak terdeteksi.

Tabel 9. Uji Multikolinearitas

\begin{tabular}{llrc}
\hline \multirow{2}{*}{ Model } & \multicolumn{2}{c}{ Collinearity } \\
\cline { 2 - 3 } & & Tolerance & VIF \\
\hline 1 & Kepemimpinan & 0,657 & 1,523 \\
& Supervisi Kepala & 0,657 & 1,523 \\
& Sekolah & & \\
\hline
\end{tabular}

Uji Hipotesis

Pengujian hipotesis diawali dengan menentukan pengaruh variabel bebas secara simultan terhadap kinerja guru sebagai variabel terikat. Model summary yang dihasilkan ditampilkan pada Tabel 10.

Tabel 10. Model Summary

\begin{tabular}{ccccc}
\hline Model & $\mathrm{R}$ & $\begin{array}{c}\mathrm{R} \\
\text { Square }\end{array}$ & $\begin{array}{c}\text { Adjusted } \\
\text { R Square }\end{array}$ & $\begin{array}{c}\text { Std. Error } \\
\text { of the } \\
\text { Estimate }\end{array}$ \\
\hline 1 & $0,839^{\mathrm{a}}$ & 0,704 & 0,699 & 0,26291 \\
\hline
\end{tabular}

a. Predictors: (Constant), Kompetensi Kepemimpinan, Supervisi

Tabel 10 menunjukkan $\mathrm{R}$ Square bernilai 0,704 atau $70,4 \%$. Nilai R Square mengisyaratkan bahwa besarnya pengaruh variabel kompetensi kepemimpinan dan supervisi kepala sekolah terhadap kinerja guru sebesar 70,4\%, dan sisanya dipengaruhi faktor lain di luar penelitian ini. Selanjutnya dilakukan perhitungan signifikansi variabel bebas terhadap variabel terikat (Tabel 11).

Tabel 11. Anova Pengaruh Kepemimpinan dan Supervisi Kepala terhadap Kinerja Guru

\begin{tabular}{lllllll}
\hline Model & & Sum of Square & $d F$ & Mean Square & F & Sig. \\
\hline 1 & Regression & 18,416 & 2 & 9,208 & 133,215 & $0,000^{\mathrm{a}}$ \\
& Residual & 7,742 & 112 & 0,069 & & \\
& Total & 26,158 & 114 & & & \\
\hline
\end{tabular}

Derajat kebebasan $(d F) \quad \mathrm{N}_{1}$ pada penelitian ini adalah 2 (jumlah variabel 1), sedangkan nilai Residual $(d F) \mathrm{N}_{2}$ adalah 112 sehingga diperoleh nilai $\mathrm{F}_{\text {tabel }}$ untuk signifikansi 5\% adalah 3,08. Berdasarkan Tabel 11 diperoleh $F_{\text {hitung }} 133,22$ ( $F_{\text {hitung }}>$ $\left.F_{\text {tabel}}\right)$ dengan signifikansi kurang dari 0,05. Hasil ini mengindikasikan adanya pengaruh positif dan signifikan antara kompetensi kepemimpinan dan supervisi kepala sekolah secara simultan terhadap kinerja guru serta model regresi linear ganda sudah sesuai.

Pengaruh kompetensi kepemimpinan kepala sekolah terhadap kinerja guru

Pengaruh kompetensi kepemimpinan terhadap kinerja guru diselidiki memakai uji-t. 
$\mathrm{H}_{0}=$ Kompetensi kepemimpinan kepala sekolah berpengaruh positif dan signifikan terhadap kinerja guru.

$\mathrm{H}_{\mathrm{a}}=$ Kompetensi kepemimpinan kepala sekolah tidak berpengaruh positif dan signifikan terhadap kinerja guru.
Dasar pengambilan keputusannya adalah jika $t_{\text {hitung }}$ lebih besar dari $t_{\text {tabel }}$ dengan signifikansi kurang dari 0,05, maka $\mathrm{H}_{0}$ ditolak dan $\mathrm{H}_{\mathrm{a}}$ diterima.

Tabel 12. Koefisien Regresi Kepemimpinan Kepala Sekolah terhadap Kinerja Guru

\begin{tabular}{llrrrrr}
\hline & & \multicolumn{2}{c}{$\begin{array}{c}\text { Unstandardized } \\
\text { Coefficient }\end{array}$} & $\begin{array}{c}\text { Standardized } \\
\text { Coefficient }\end{array}$ & \multirow{2}{*}{ S } & Sig. \\
\cline { 3 - 7 } Model & & \multicolumn{1}{c}{ B } & Std. Error & Beta & & \\
\hline 1 & (Constant) & 0,231 & 0,180 & & 1,278 & 0,204 \\
& Kompetensi Kepemimpinan & 0,455 & 0,057 & 0,505 & 7,962 & 0,000 \\
\hline
\end{tabular}

Penentuan $t_{\text {tabel }}$ dilakukan dengan terlebih dahulu mengetahui nilai derajat kebebasan. Nilai derajat kebebasan $(\mathrm{dF})$ adalah 113 (jumlah sampel - jumlah variabel). Berdasarkan nilai derajat kebebasan yang telah diketahui, maka nilai $\mathrm{t}_{\text {tabel }}$ untuk signifikansi $5 \%$ adalah 1,658. Nilai $t_{\text {hitung }}$ pada Tabel 12 sebesar 7,962 $\left(t_{\text {hitung }}>t_{\text {tabel }}\right)$ dengan signifikansi kurang dari 0,05 , dengan demikian $\mathrm{H}_{\mathrm{a}}$ diterima dan $\mathrm{H}_{0}$ ditolak. Hasil ini mengindikasikan kompetensi kepemimpinan berpengaruh positif dan signifikan terhadap kinerja guru. Pengaruh yang besar dapat ditentukan dengan mengetahui nilai koefisien Beta (Standardized Coefficient). Pengaruh kompetensi kepemimpinan berdasarkan Tabel 12 sebesar 0,505 atau 50,5\%.
Pengaruh supervisi kepala sekolah terhadap kinerja guru

Pengaruh supervisi terhadap kinerja guru diselidiki dengan uji-t. Pada pengujian ini dirumuskan hipotesis sebagai berikut:

$\mathrm{H}_{0}=$ Supervisi kepala sekolah berpengaruh positif dan signifikan terhadap kinerja guru.

$\mathrm{H}_{\mathrm{a}}=$ Supervisi kepala sekolah tidak berpengaruh positif dan signifikan terhadap kinerja guru.

Pengambilan keputusannya adalah jika $t_{\text {hitung }}$ lebih besar dari $t_{\text {tabel }}$ dengan signifikansi kurang dari 0,05 , maka $\mathrm{H}_{0}$ ditolak dan $\mathrm{H}_{\mathrm{a}}$ diterima. Koefisien regresi sederhana pengaruh supervisi terhadap kinerja guru ditunjukkan pada Tabel 13.

Tabel 13. Koefisien Regresi Pengaruh Supervisi Kepala Sekolah terhadap Kinerja Guru

\begin{tabular}{llrrrrr}
\hline & & \multicolumn{2}{c}{$\begin{array}{c}\text { Unstandardized } \\
\text { Coefficient }\end{array}$} & $\begin{array}{c}\text { Standardized } \\
\text { Coefficient }\end{array}$ & \multirow{2}{*}{$T$} & \multirow{2}{*}{ Sig. } \\
\cline { 3 - 7 } Model & & B & Std. Error & Beta & & \\
\hline 1 & (Constant) & 0,231 & 0,180 & & 1,278 & 0,204 \\
& Supervisi Kepala Sekolah & 0,489 & 0,071 & 0,436 & 6,880 & 0,000 \\
\hline
\end{tabular}

Penentuan $t_{\text {tabel }}$ dilakukan dengan terlebih dahulu mengetahui nilai derajat kebebasan. Nilai derajat kebebasan $(\mathrm{dF})$ adalah 113. Dengan demikian nilai $t_{\text {tabel }}$ untuk signifikansi $5 \%$ adalah 1,658. Nilai

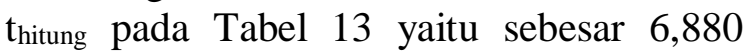
$\left(>t_{\text {tabel }}\right)$ dengan signifikansi kurang dari 0,05, sehingga terima $\mathrm{H}_{\mathrm{a}}$ dan tolak $\mathrm{H}_{0}$. Dengan demikian supervisi kepala sekolah berpengaruh positif dan signifikan terhadap kinerja guru sebesar 0,436 atau $43,6 \%$.

Pengaruh kompetensi kepemimpinan dan supervisi kepala sekolah secara Simultan terhadap kinerja guru

Hasil pengujian yang ditampilkan pada Tabel 11 mengonfirmasi ada pengaruh positif dan signifikan antara kompetensi kepemimpinan dan supervisi terhadap 
Jurnal Edumaspul, 5 (1), Year 2021- 538

(Kristoforus Buku, Achadi Budi Santosa, Sukirman, Enung Hasanah)

kinerja guru. Selanjutnya dilakukan linear ganda yang ditawarkan (Tabel 14). perhitungan koefisien regresi model regresi

Tabel 14. Koefisien Regresi Kepemimpinan dan Supervisi Kepala terhadap Kinerja Guru

\begin{tabular}{|c|c|c|c|c|c|c|}
\hline \multirow[b]{2}{*}{ Model } & & \multicolumn{2}{|c|}{$\begin{array}{c}\text { Unstandardized } \\
\text { Coefficient }\end{array}$} & \multirow{2}{*}{$\begin{array}{c}\begin{array}{c}\text { Standardized } \\
\text { Coefficient }\end{array} \\
\text { Beta }\end{array}$} & \multirow[t]{2}{*}{$t$} & \multirow[t]{2}{*}{ Sig. } \\
\hline & & $B$ & $\begin{array}{l}\text { Std. } \\
\text { Error }\end{array}$ & & & \\
\hline 1 & $($ Constant $)$ & 0,231 & 0,180 & & 1,278 & 0,204 \\
\hline & Kompetensi Kepemimpinan & 0,455 & 0,057 & 0,505 & 7,962 & 0,000 \\
\hline & Supervisi Kepala Sekolah & 0,489 & 0,071 & 0,436 & 6,880 & 0,000 \\
\hline
\end{tabular}

Persamaan regresi linear ganda yang dapat disusun berdasarkan hasil perhitungan nilai koefisien tiap variabel adalah sebagai berikut:

$Y=C+\beta_{1} X_{1}+\beta_{2} X_{2}$

$Y=0,231+0,455 X_{1}+0,489 X_{2}$

Pembahasan

Kompetensi kepemimpinan kepala sekolah menjadi salah satu faktor utama dalam menentukan keberhasilan yang dapat dicapai sekolah, baik dari kualitas output (peserta didik) maupun kinerja tenaga pendidik (guru) selama proses pembelajaran. Hasil yang diperoleh pada penelitian ini menunjukkan adanya pengaruh positif dan signifikan antara kompetensi kepemimpinan kepala sekolah terhadap kinerja guru SMP di Kabupaten Nagekeo sebesar 50,5\%.

Lantip dan Sudiyono (dalam Yohanas, 2018) berpendapat bahwa kepala sekolah sebagai supervisor harus mampu merencanakan, melaksanakan dan mengevaluasi program supervisi dalam rangka menciptakan situasi yang kondusif dan mendukung peningkatan kualitas pengetahuan, keterampilan, sikap, kedisiplinan dari masing-masing guru. Pada penelitian ini, pengaruh supervisi kepala sekolah terhadap kinerja guru secara parsial memperoleh nilai thitung 6,880 yang lebih besar dari $t_{\text {tabel }}(1,658)$ dengan signifikansi $0,000 \quad(<0,05)$ sehingga dapat dikatakan, supervisi kepala sekolah berpengaruh positif dan signifikan terhadap kinerja guru. Besarnya pengaruh supervisi kepala sekolah terhadap kinerja guru SMP di Kabupaten Nagekeo adalah 43,6\%.

Pengaruh kompetensi kepemimpinan dan supervisi kepala sekolah secara bersama-sama dijelaskan oleh hasil uji F. Nilai $F_{\text {hitung }}$ yang diperoleh pada penelitian ini sebesar 133,215 ( $\left.F_{\text {hitung }}>F_{\text {tabel }}\right)$ dengan signifikansi 0,000 (sig. $<0,05$ ), sehingga dapat disimpulkan bahwa terdapat pengaruh positif dan signifikan secara bersama-sama antara kompetensi kepemimpinan dan supervisi kepala sekolah terhadap kinerja guru. Besarnya pengaruh tersebut diwakili oleh nilai $\mathrm{R}$ Square (pada penelitian ini, diperoleh nilai R Square sebesar 0,704). Dengan demikian, dapat disimpulakan bahwa besarnya pengaruh kompetensi kepemimpinan dan supervisi kepala sekolah terhadap kinerja guru SMP di Kabupaten Nagekeo secara bersama-sama adalah $70,4 \%$ sedangkan $29,6 \%$ dipengaruhi oleh variabel lain. Hasil ini juga sejalan dengan hasil penelitian yang dipublikasikan oleh Hardono, Haryono \& Yusuf (2017) dengan nilai $F_{\text {hitung }} 51,172$.

Regresi linear ganda yang dilakukan menghasilkan nilai C (Constant) sebesar 0,231 . Hasil ini mengindikasikan besarnya kinerja guru ketika tidak dipengaruhi oleh kompetensi kepemimpinan dan supervisi kepala sekolah. Koefisien regresi variabel kompetensi kepemimpinan menunjukkan angka positif $(0,455)$, artinya kompetensi kepemimpinan kepala sekolah berpengaruh positif terhadap kinerja guru. Jika terjadi peningkatan pada variabel kompetensi kepemimpinan kepala sekolah sebanyak $1 \%$, maka kinerja guru akan bertambah 
sebanyak 45,5 poin. Variabel supervisi kepala sekolah juga menunjukkan pengaruh positif terhadap kinerja guru dengan nilai koefisien regresi 0,489. Peningkatan sebanyak $1 \%$ pada variabel supervisi kepala sekolah menyebabkan kinerja guru bertambah sebanyak 48,9 poin.

\section{Simpulan}

Kompetensi kepemimpinan kepala sekolah secara parsial berpengaruh positif dan signifikan terhadap kinerja guru SMP di Kabupaten Nagekeo dengan besar pengaruh 50,5\%. Supervisi kepala sekolah memiliki kontribusi positif dan signifikan sebesar 43,6\% terhadap kinerja guru SMP di Kabupaten Nagekeo. Secara simultan, kompetensi kepemimpinan dan supervisi kepala sekolah berkontribusi sebanyak $70,4 \%$ terhadap kinerja guru SMP di Kabupaten Nagekeo.

Peneliti menyarankan agar kepala sekolah perlu memaksimalkan kompetensi yang dimiliki serta menjadi supervisor yang tidak sekedar menjalankan supervisi karena tuntutan administrasi.

\section{Ucapan Terima Kasih}

Terima kasih kepada pemerintah daerah Kabupaten Nagekeo, Provinsi Nusa Tenggara Timur yang telah mendukung peneliti melalui pemberian beasiswa Pascasarjana mulai tahun anggaran 2019/2020 sampai selesai. Terima kasih juga disampaikan kepada Universitas Ahmad Dahlan Yogyakarta yang telah mempercayakan peneliti untuk mengeyam pendidikan pascasarjana bidang Manajemen Pendidikan.

\section{Daftar Pustaka}

[1] Adi. (2016). Implementasi Kompetensi Manajerial Kepala Sekolah Kecamatan Kuala Kampar Kabupaten Pelalawan Propinsi Riau. Jurnal Akuntabilitas Manajemen Pendidikan, 4, 1-16. https://doi.-org/10.5151/cidi2017060
[2] Amanda, M. O., Salam, R., \& Saggaf, S. (2017). Pengaruh Supervisi Kepala Sekolah Terhadap Kinerja Guru Di SMK Negeri 1 Bungoro Kabupaten Pangkep. Prosiding Seminar Nasional Himpunan Sarjana Ilmu-Ilmu Sosial, 2, 149-154. Retrieved from https://ojs.unm.ac.id/PSNHSIS/article/view/2739.

[3] Evriani, L., Sasongko, R. N., \& Juarsa, O. (2017). Supervisi Akademik Kepala Sekolah Dalam Upaya Membantu Guru Mengatasi Kesulitan Mengajar Di Smp. Manajer Pendidikan, 11(5), 447-454. Retrieved from https://ejournal.unib.ac.id/index.php/manajerpendidikan/arti cle/viewFile/3351/1762.

[4] Hardono., Haryono., \& Yusuf, A. (2017). Kepemimpinan Kepala Sekolah, Supervisi Akademik, dan Motivasi Kerja dalam Meningkatkan Kinerja Guru. Educational Management, 6(1), 26-33. Retrieved from http://journal.unnes.ac.id/sju/index.php/eduman

[5] Helmiawan, M., Akbar, Y., \& Sofian, Y. Y. (2019). Evaluasi dan Uji Kualitas Website dengan Metode Webqual (Studi Kasus: STMIK Sumedang). Journal of Information Technology, 1(1), 1-4. https://doi.org/10.47292/joint.v1i1.5

[6] Herly. (2014). "Upaya Kepala Sekolah Meningkatan Pelaksanaan Supervisi di Sekolah Dasar 015 Kempas." Jurnal Administrasi Pendidikan, 2(1), 312 314. Retrieved from http://ejournal.unp.ac.id/index.php/bahana/article/dow nload/3767/3001.

[7] Indrawati, E., Somantri, M., Juarsa, O. (2017). Implementasi Supervisi Akademik di SMP. Manajer Pendidikan, 11(5), 491-497. Retrieved from https://ejournal.unib.ac.id/index.$\mathrm{php} /$ manajerpendidikan/article/downlo $\mathrm{ad} / 3358 / 1765$. 
[8] Indriyani, Y., \& Suparjo. (2018). Pengaruh Kompetensi Pedagogik , dan Motivasi Kerja Terhadap Kinerja Guru SMK Bhakti Praja Kabupaten Batang. Serat Acitya - Jurnal Ilmiah UNTAG Semarang, 7(2), 88-101. Retrieved from http://jurnal.untagsmg.ac.id/index.php/sa/article/view/890.

[9] Isjoni, I., Sumardi, S., \& Natuna, D. A. (2017). The Effect of School Principal Supervision on Teacher Professionalism in SMA Pekanbaru. International Journal of Educational Best Practices, 1(2), 50-58. https://doi.org/10.31258/ijebp.v1n2.p50-58

[10] Kementerian Pendidikan dan Kebudayaan Republik Indonesia. 2020. Retrieved from https://dapo.dikdasmen.kemdikbud.go.id/guru/2/241700

[11] Lestari, S. (2018). Analisis Standar Pendidik Dan Tenaga Kependidikan. Nidhomul Haq, 3(April), 18-22. https://doi.org/10.-31538/ndh.v3i1.35

[12] Lilliefors, H. W. (1967). On the Kolmogorov-Smirnov Test for Normality with Mean and Variance Unknown. Journal of American Statistics, 62(318), 399-402. https://doi.org/10.2307/2283970

[13] Mardiyati, U., Ahmad, G. N., \& Ria, P. (2012). Pengaruh Kebijakan Dividen, Kebijakan Hutang Dan Profitabilitas Terhadap Nilai Perusahaan Manufaktur Yang Terdaftar Di Bursa Efek Indonesia Periode 2005-2010. Jurnal Riset Manajemen Sains Indonesia, 3(1), 1-17. https://doi.org/10.35794/emba.v8i4.30859
[14] Mukhtar. (2015). Strategi Kepala Sekolah Dalam Meningkatkan Kinerja Guru Pada Smp Negeri Di Kecamatan Masjid Raya Kabupaten Aceh Besar. Jurnal Magister Administrasi Pendidikan, 3(3), 103-117. https://doi.org/10.24090/jk.v5i2.1931

[15] Nurjanah, N. (2011). Pengaruh profesionalisme guru terhadap prestasi siswa pada mata pelajaran al Qur'an Hadits di madrasah ibtidaiyah se kecamatan Gemuh kabupaten Kendal tahun 2010. IAIN Walisongo. Retrieved from http://eprints.walisongo.ac.id/2499/

[16] Selvia. (2015). Implementasi supervisi akademik kepala sekolah dalam peningkatan profesionalisme guru. Manajer Pendidikan, 9, 43-49. Retrieved from https://ejournal.unib.ac.id/index.php/manajerpendidika n/article/download/1096/907.

[17] Sutrisno, N., Ashadi, W., Tanjung, H. F., \& Tyas, A. K. (2020). Descriptive Analysis Using a Frequency Distribution to Determine the Highest Number of Publication in Focus Area of Defense and Security. IOP Conference Series: Earth and Environmental Science, 448(1). https://doi.org/10.1088/17551315/448/1/0-12078

[18] Yohanas, R. (2018). Pengaruh Supervisi Kepala Sekolah Dan Komunikasi Antar Pribadi Terhadap Kepuasan Kerja Guru Sd Negeri SeKecamatan Lima Kaum. Al-Fikrah: Jurnal Manajemen Pendidikan, 6(1), 33-44. https://doi.org/10.31958/jaf.v6i1.1375. 